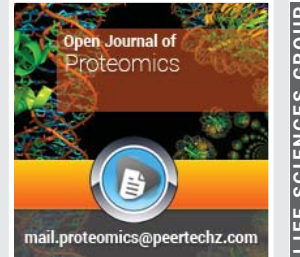

\section{COVID-19 and SARS-CoV-2:} Despite the vaccination, new targets/drugs for treatment and the virus cycle mechanisms still have to be continually investigated

\section{Victor GO Evangelho', Camila F Mattos ${ }^{2}$, Marcia R Amorim", Juliana S Novais ${ }^{2}$, Marcos K Veiga ${ }^{1}$, Murilo L Bello ${ }^{3 *}$ and Helena C Castro ${ }^{1,2 *}$}

1Post-graduation in Science and Biotechnology, IB, Fluminense Federal University, Niterói, Rio de Janeiro, Brazil

${ }^{2}$ Post-graduation in Pathology, Faculty of Medicine, Fluminense Federal University, Niterói, Rio de Janeiro, Brazi

${ }^{3}$ Department of Drugs and Medicines, Faculty of Pharmacy, Fluminense Federal University, Niterói, Rio de Janeiro, Brazil
Received: 25 January, 2021

Accepted: 09 February, 2021

Published: 10 February, 2021

*Corresponding author: Helena C Castro, Post-graduation in Science and Biotechnology, IB, Fluminense Federal University, Niterói, Rio de Janeiro, Brazil, E-mail:hcastro@id.uff.br

Murilo L Bello, Department of Drugs and Medicines, Faculty of Pharmacy, Fluminense Federal University, Niterói, Rio de Janeiro, Brazil,

E-mail:murilolamim@pharma.ufrj.br

https://www.peertechz.com

\section{Check for updates}

\begin{abstract}
Several countries are suffering with COVID-19 second wave that has been worse than the first one. In addition, new challenges are being imposed by new mutations and their high transmissibility, such as B.1.1.7, identified in the United Kingdom, and the strains P.1 and 501Y.V2, from Brazil and South Africa, respectively. They threaten the immune effects of the new launched vaccines (eg.: Coronavax, Oxford vaccine, and Sputnik) as nobody can assure their effectiveness against all coronavirus mutants that are still ahead. Finally, vaccination of the whole population against coronavirus, as it is done for influenza in the elderly people, is financially very difficult, especially in the low-income countries. Therefore, this brief 2-page opinion comes to highlight the fact that, similar to HIV infection (AIDS), COVID-19 will need continuous research about the virus cycle mechanisms and drug design/searching for new antivirus that may treat those infected with this still unknown virus to avoid its major effects and high lethality worldwide.
\end{abstract}

In a growing global effort to combat the fatal spread of SARS-CoV-2, while vaccines are released and delivered as fast as the pharmaceutical companies can, to restrict and decrease the death worldwide; several drugs are being reused in patients infected by coronavirus [1]. Meanwhile, several countries are suffering with the COVID-19 second wave, that shown to be worse than the first one, affecting especially countries such as USA and Brazil that did not assume the necessary measures involving mask-use everywhere and isolating individuals in their homes, especially the risk groups $[2,3]$.

Despite the vaccines distribution, the fact is that we still lack a systematic research about long-term risks such as those regarding the vaccines using mRNA, especially related to pregnant women, due to the absence of data for reproductive toxicology and reactogenicity in this group [4]. In this context, 
it is important to emphasize the scientific advances and important points that it is still up to us, as scientists, to make efforts to have more data that will help us in the development of new strategies and the direction of the pandemic as well as in the post-pandemic period [5].

After a brief evaluation of the literature in the last and present years using keywords coronavirus, COVID-19, treatment and vaccine in different platforms including MEDLINE, Google Scholar, Scopus, Web of Science, and Science Direct, it is possible to observe that to fight against coronavirus, the vaccine development has focused on the Spike Sars-Cov-2 receptor. This virus has an RNA genome (ssRNA (+) that uses the ACE2 receptor to invade the host cell through [6]. Through this mechanism several vaccines have been designed and approved by regulatory agencies in recent months [7]. Among them, we may cite the vaccines for RNA of companies such as Moderna, Pfizer and the recombinant virus of Oxford / Astrazenica, among others [8] (Figure 1).

However, new challenges are being imposed by new mutations and the high transmissibility of new strains, such as B.1.1.7, identified in the United Kingdom, as well as the strains P.1 and 501Y.V2, identified in Brazil and South Africa, respectively [9]. Thus, genomics patrol needs to be strengthened in countries with low investment in genomics, given the risks of not identifying several uncatalogued strains that may pose risks to vaccines already implemented in immunization strategies in several countries [10].

On that purpose, the global vaccine development huge effort should also be similar to repositioning drugs or developing new pharmacological alternatives, such as new antivirals [11]. In addition, it is also important to analyze more carefully the use of antimicrobials (eg. Azithromycin), antifungi and/or antiparasites (eg. ivermectin) that were common during this pandemic, which tried to somehow stop the virus, even the efficacy was not a sure result at all (eg. hydroxychloroquine and chloroquine) [11-13]. Furthermore, the use of monoclonal antibodies and Hyperimmune sera still has to be explored as they are also on evaluation when it comes to human subject phase trials (eg. Phase 3) [11,12] (Figure 1).

Although in a lower extent, this coronavirus will continue to infect us over the next years as predicted by most researchers, even after the vaccination of the world population [14]. Considering not only this scenario, but also the possibility of infecting germ cells that can result in developmental conditions in the next generation worldwide, studying this virus is clearly still a huge demand [15,16]. Evolutively, it is important to highlight the necessity of studies on pregnant subjects involving COVID-19. The relationship between viral and human endogenous viral material has been known for decades and the indicators based on genomic sequencing and alignment of homologous sequences show that at least $8 \%$ of the human genome may be of viral origin $[17,18]$.

It is interesting as evolutionary studies show that virus and human interface as a natural process for inducing human variability. From the protein-coding or by integrating a regulatory region, this process still lacks the viral genome fragment fixation in the population $[19,20]$. In this context, it should be noted that the proteins ARC and HERV-W are among the proteins that act on the human body and, they believe to be of viral origin and that they were assimilated by the genome [21]. In the physiological mechanism, the ARC protein is important for the functioning of the central nervous system, associated with synaptic plasticity [22]. HERV-W is involved in human placental development [23].

\section{Conclusion}

Despite the low possibility of another new pandemic after the vaccination of the people worldwide, we should not ignoreSARS-CoV-2 mutation capability. Thus, we should

\section{ton}

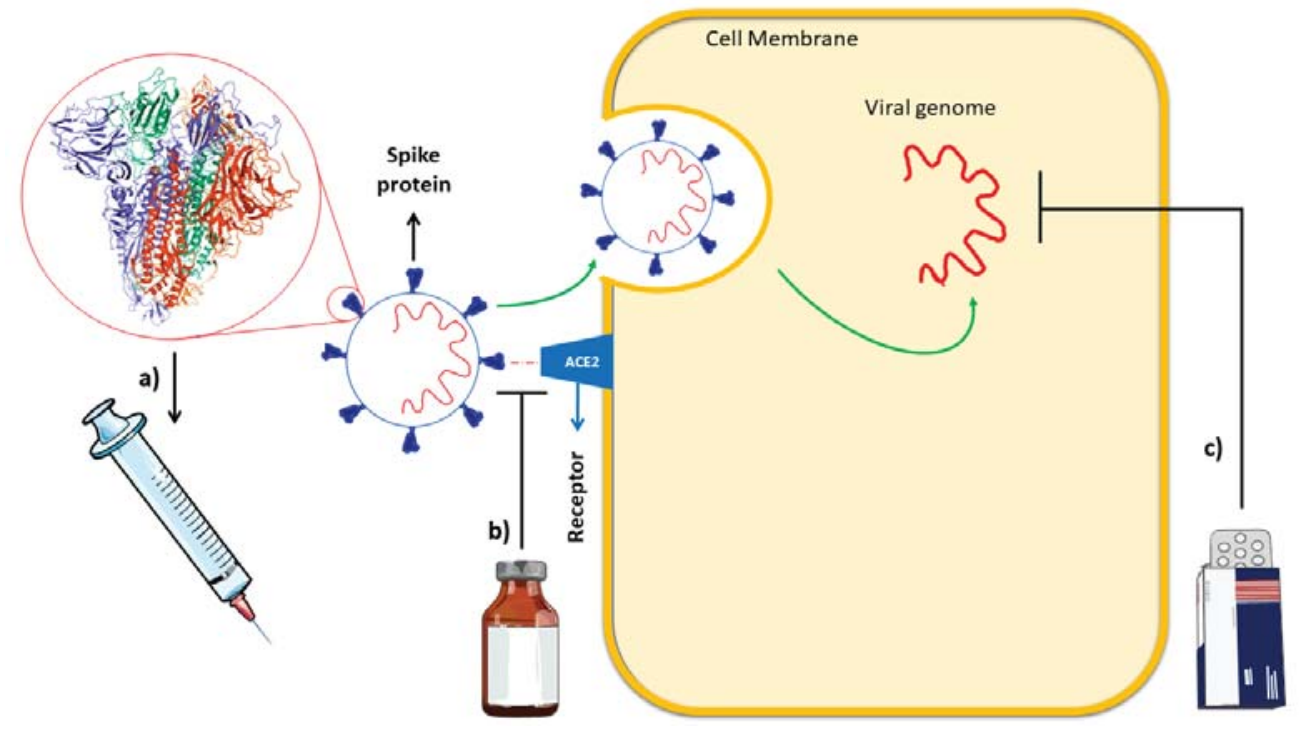

Figure 1: Feasible treatment propositions against coronavirus. a) The use of spike protein (PDB: 6acc) for vaccine development to human immunization. b) Targeting SarsCov-2 interaction with host receptor by inhibitory drug development. c) Targeting the viral genome translation and transcription by inhibitory drug development (part from http://smart.servier.com/, demobilized under creative commons 3.0 license). 
continue to investigate, such as happened with HIV/AIDS $[24,25]$ not only its infection cycle, including germ cells tests, but also its relationship with bacteria, fungi and parasites, as well as new targets and drugs for treatment. On that matter, proteomic and genomic studies are important since they can generated data that can be compared and combined with other in vitro, in vivo and in silico results, leading to new useful and applied knowledge, drugs and treatments against this deadly disease.

\section{References}

1. Yufika A, Luther A, Nawawi Y, Wahyuniati N, Anwar S, et al. (2020) Parents' hesitancy towards vaccination in Indonesia: A cross-sectional study in Indonesia. Vaccine 38: 2592-2599. Link: https://bit.ly/3a0rINI

2. Tollefson $\mathrm{J}$ (2020) How Trump damaged science - and why it could take decades to recover. Nature 586: 190-194. Link: https://bit.ly/3qgIR6

3. The Lancet (2020) COVID-19 in Brazil: "So what?" The Lancet 395: 1461. Link: https://bit.ly/3cWpZF

4. Rasmussen SA, Kelley CF, Horton JP, Jamieson DJ (2021) Coronavirus Disease 2019 (COVID-19) Vaccines and Pregnancy: What Obstetricians Need to Know. Obstetrics \& Gynecology, Obstet Gynecol Feb 4. Link: https://bit.ly/3jxbYQ0

5. Yi Y, Lagniton PNP, Ye S, Li E, Xu RH (2020) COVID-19: What has been learned and to be learned about the novel coronavirus disease. Int J Biol Sci 16: 17531766. Link: https://bit.ly/3jDYguL

6. Cao Y, Li L, Feng Z, Wan S, Huang P, Sun X, et al. (2020) Comparative genetic analysis of the novel coronavirus (2019-nCoV/SARS-CoV-2) receptor ACE2 in different populations. Cell Discov 6: 4-7. Link: https://bit.ly/3cTLwPc

7. Gorbalenya AE, Baker SC, Baric RS, Groot RJ De, Gulyaeva AA, et al. (2020) The species Severe acute respiratory syndrome-related coronavirus: classifying 2019-nCoV and naming it SARS-CoV-2. Nat Microbiol 5: 536-544. Link: https://go.nature.com/3cW9qJR

8. Defendi HGT, Madeira LS, Borschiver S (2021) Analysis of the COVID-19 Vaccine Development Process: an Exploratory Study of Accelerating Factors and Innovative Environments. J Pharm Innov 1-17. Link: https://bit.ly/3rH5st3

9. Toovey OTR, Harvey KN, Bird PW, Tang JWTWT (2021) Introduction of Brazilian SARS-CoV-2 484K.V2 related variants into the UK. Journal of Infection 2-5. Link: https://bit.ly/3cTLbfo

10. Le Page $M$ (2021) Threats from new variants. New Sci 249: 8-9. Link: https://bit.ly/2MOMQIv

11. Costa C, Martins F, Cunha L, Ratcliffe N, Paula R, et al. (2021) COVID-19 and Hyperimmune sera: A feasible plan B to fight against coronavirus. Int Immunopharmacol 90: 107220. Link: https://bit.ly/3cWn4gq

12. Cimerman S, Chebabo A, Cunha CA da, Rodríguez-Morales AJ (2020) Deep impact of COVID-19 in the healthcare of Latin America: the case of Brazil. Braz J Infect Dis 24: 93-95. Link: https://bit.ly/3p5sZSB

13. Tian X, Li C, Wu Y, Ying T (2021) Insights into biological therapeutic strategies for COVID-19. Fundamental Research. Link: https://bit.ly/3ryiSaA

14. Veldhoen M, Simas JP (2021) Endemic SARS-CoV-2 will maintain post-pandemic immunity. Nature Reviews Immunology. Link: https://bit.ly/2MFU9CA
15. Eiden M (2008) Multi-author Review Endogenous retroviruses Coordinator: M. V. Eiden. Cellular and Molecular Life Sciences 65: 3327-3328. Link: https://bit.ly/20cCfal

16. Hayward A, Cornwallis CK, Jern P (2015) Pan-vertebrate comparative genomics unmasks retrovirus macroevolution. Proceedings of the National Academy of Sciences of the United States of America 112: 464-469. Link: Link: https://bit.ly/3q3q03h

17. Grifoni A, Sidney J, Zhang Y, Scheuermann RH, Peters B, et al. (2020) A Sequence Homology and Bioinformatic Approach Can Predict Candidate Targets for Immune Responses to SARS-CoV-2. Cell Host and Microbe 27 671-680.e2. Link: https://bit.ly/2Lx1TGc

18. Katsura Y, Asai S (2019) Evolutionary Medicine of Retroviruses in the Human Genome. American Journal of the Medical Sciences 358: 384-388. Link: https://bit.ly/3aR6llm

19. Katzourakis A, Gifford RJ (2010) Endogenous viral elements in animal genomes. PLoS Genetics 6. Link: https://bit.ly/3jA6kwK

20. Khodosevich K, Lebedev Y, Sverdlov E (2002) Endogenous retroviruses and human evolution. Comparative and Functional Genomics 3: 494-498. Link: https://bit.ly/3a2vr8j

21. Bandyopadhyay S, Baticulon RE, Kadhum M, Alser M, Ojuka DK, et al (2020) Infection and mortality of healthcare workers worldwide from COVID-19: A systematic review. BMJ Global Health 5: e003097. Link: https://bit.ly/3qgHDrL

22. Pastuzyn ED, Day CE, Kearns RB, Kyrke-Smith M, Taibi AV, et al. (2018) Erratum: The Neuronal Gene Arc Encodes a Repurposed Retrotransposon Gag Protein that Mediates Intercellular RNA Transfer. Cell 173: 275-288. Link: https://bit.ly/3a4SEqp

23. Bolze PA, Mommert M, Mallet F (2017) Contribution of Syncytins and Othe Endogenous Retroviral Envelopes to Human Placenta Pathologies. Progress in Molecular Biology and Translational Science (1st ed., Vol. 145). Elsevier Inc Link: https://bit.ly/2NdllHh

24. Yang J, Zheng Y, Gou X, Pu K, Chen Z, et al. (2020) International Journal of Infectious Diseases Prevalence of comorbidities and its effects in patients infected with SARS-CoV-2 : a systematic review and meta-analysis. Int J Infect Dis 94: 91-95. Link: https://bit.ly/3jwFlwi

25. Ratcliffe NA, Castro HC, Paixão IC, Mello CB (2021) COVID-19: Innovative Antiviral Drugs Required for Long-Term Prevention and Control of Coronavirus Diseases. Curr Med Chem 28: 42-55.

Discover a bigger Impact and Visibility of your article publication with Peertechz Publications

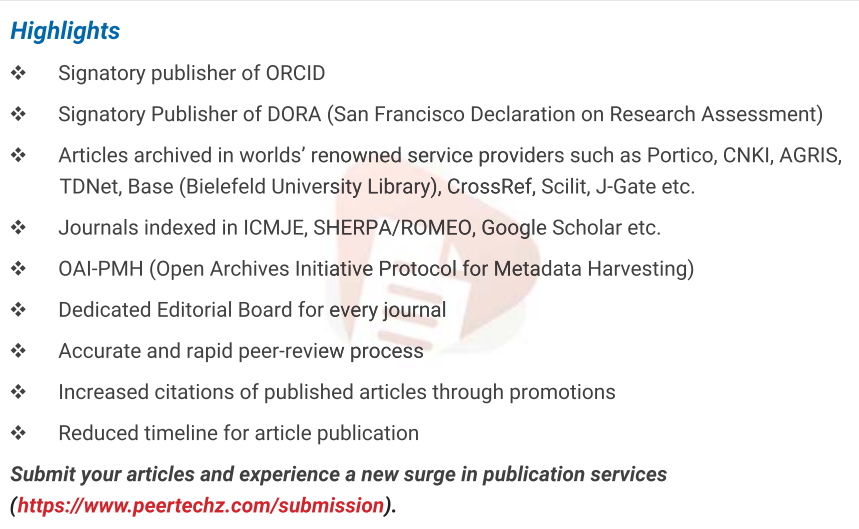

Peertechz journals wishes everlasting success in your every endeavours.

Copyright: @ 2021 Evangelho VG, et al. This is an open-access article distributed under the terms of the Creative Commons Attribution License, which permits unrestricted use, distribution, and r eproduction in any medium, provided the original author and source are credited.

Citation: Evangelho VG, Mattos CF, Amorim MR, Novais JS, Castro HC, et al. (2021) COVID-19 and SARS-CoV-2: Despite the vaccination, new targets/drugs for treatment and the virus cycle mechanisms still have to be continually investigated. Open J Proteom Genom 6(1): 001-003. 